\title{
Factors Of The Formation Of New Autonomous Regions And Its Impact On State Finances
}

\section{Arief Maulana}

Center for Regional and Budget Studies,

General Secretariat of the Indonesian Republic's Regional Representative Council

Jln. Jenderal Gatot Subroto, No.6, Jakarta Pusat, Indonesia, 10270

maulana_arief@ymail.com

\begin{tabular}{|c|c|}
\hline Article Info & Abstract \\
\hline $\begin{array}{l}\text { Clause history: } \\
\text { Received Juny 22,2019 } \\
\text { Revised July 01,2019 } \\
\text { Accepted July 20,2019 } \\
\text { Available online August } \\
30,2019\end{array}$ & $\begin{array}{l}\text { The purpose of this study is to analyze the driving } \\
\text { factors of the formation of new autonomous regions in } \\
\text { Indonesia during the reformation era and its impact on } \\
\text { state finance. This study is a policy study by collecting } \\
\text { data and then analyzing it into a conclusion and } \\
\text { recommendation. This type of study is a literature study } \\
\text { with the method used is descriptive qualitative method. }\end{array}$ \\
\hline $\begin{array}{l}\text { Keywords: } \quad \text { New } \\
\text { Autonomous } \quad \text { Region; } \\
\text { Government Policy; State } \\
\text { Finance } \\
\text { JEL Classification : E62; } \\
\text { G32; G40 }\end{array}$ & $\begin{array}{l}\text { The results of the study show that since the reform era, } \\
\text { the formation of a new autonomous region has been very } \\
\text { massive. If calculated on average from } 1999 \text { to } 2014 \text {, } \\
\text { each year the new regions increase by } 13 \text { regions per } \\
\text { year. The formation of the new autonomous regions } \\
\text { requires considerable preparation and costs, starting } \\
\text { from the initial formation to the implementation. In } \\
\text { addition, in general the new autonomous regions show } \\
\text { higher fiscal dependencies than the old regions. Thus, it } \\
\text { can be stated that the establishment of the new } \\
\text { autonomous regions has caused pressure on the state } \\
\text { finances due to the large amount of funds that must be } \\
\text { transferred to new regions. }\end{array}$ \\
\hline
\end{tabular}

\section{INTRODUCUTION}

The relationship between the central government and regional government is inseparable from the discussion of the form of the state, because the relationship between the two is strongly influenced by the form of the state. According to modern political theories, the form of the state is broadly divided into two main forms, namely a single tiered state, called the unitary state and the plural state, called the federal state (Soehino, 1999). C.F. Strong states that a unitary state is a form of state in which the highest legislative authority is centralized within a national legislative body. Power lies with the central government and does not lie with local governments. The central government has the authority to hand over part of its power to the regions based on the right of autonomy (a unitary state with a decentralized system), but in the final stage the highest power remains in the hands of the central government, both inward and outward sovereignty, entirely resting with the central government (Budiardjo, 2013).

Indonesia as a unitary state in the administration of its administration in the regions is based on the principles of decestralization, deconcentration, and co-administration. The second amendment to constitution of the Republic of Indonesia states that "The Unitary State of the Republic of

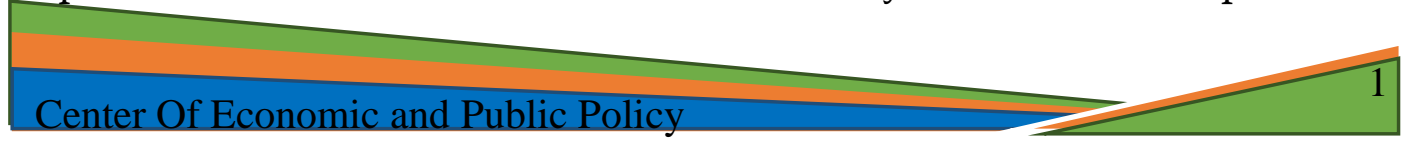


Indonesia is divided into provincial regions and the provincial region is divided into regency and city areas, each of which has a regional government regulated by law". In accordance with this clause the Indonesian government system recognizes the existence of a central government and regional governments. The division of territory is divided into provinces, districts and cities that have their own government, so the relationship between the central government and regional governments (provincial, district and city) is verticalhierarchical. Constitution states that regional governments carry out the broadest possible autonomy, except governmental affairs which by law are determined to be the affairs of the central government.

The implementation of regional autonomy as clearly mandated in the 1945 Constitution, is intended to organize the regional government system within the framework of the Republic of Indonesia. The implementation is done by giving freedom to the regions to carry out governmental authority at the regional level. The autonomy granted to regencies and cities is carried out by giving proportional, broad, and accountable authority to regional governments. This means that the delegation of responsibilities will be followed by arrangements for distribution, equitable use of national resources, and financial balance. Since the reform era, several laws have been enacted governing local governments ranging from Law Number 22 Year 1999, Law Number 32 Year 2004 and Law Number 23 Year 2014. Since the enactment of Law Number 22 Year 1999 to Law Number 23 Year 2014 there have been many autonomous regions formed by the government, both provincial and district / city.

Philosophically, the aim of regional expansion is three interests, namely improving public government services to the community and improving the welfare of local communities, and shortening the range of government control (Siswanto, 2012). Regional expansion is a phenomenon that accompanies the administration of regional government in Indonesia. This can be seen from the increase in the number of new autonomous regions in the territory of the Republic of Indonesia. To date there are 542 autonomous regions consisting of 34 provinces, 415 districts and 93 cities (excluding 1 administrative district and 5 administrative cities in DKI Jakarta Province). Therefore, the presence of the new autonomous regions is expected to be able to improve services and welfare for the community. This is as mandated by the spirit of regional autonomy contained in Law Number 23 of 2014 in conjunction with Law Number 09 of 2015.

Based on data from the Directorate General of Regional Autonomy, the period 1999-2004 has formed 7 provinces, 115 districts and 26 new cities. In 2005-2014 a new autonomous region was formed, consisting of 1 province, 67 districts and 7 cities. Since the taps for the formation of a new autonomous region were opened in 1999 until now, the state has authorized 237 new districts / cities. Not only does it stop at the formation of new regions, the regional autonomy policy also encourages accelerated regional development through the transfer of funds from the center to the regions that continues to increase (Ministry of Internal Affairs, 2017).

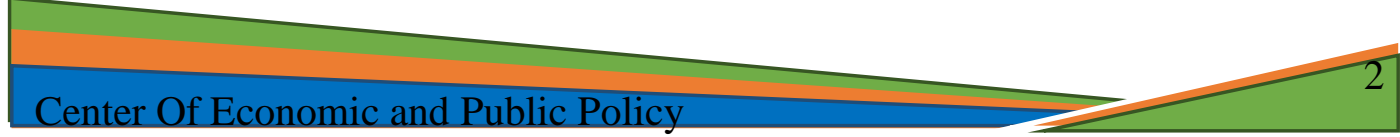


Facts that occur in the regions actually say differently, every year the public of the homeland is treated to more facts about the corrupt practices of regional officials. Data on the rampant corruption carried out by regional officials shows that funds transferred to the regions actually become easy targets to be misused. On the other hand, in the eyes of some economists, the country's finances are currently very worrying. The burden of infrastructure projects that absorb large funds does not offset the abundant revenues. This condition can widen the budget deficit to above 3\% of Gross Domestic Product (GDP) by the end of this year, or exceed the maximum threshold set by the Law on State Finance (Wijaya, 2017).

This condition will be seen as a fiscal risk that makes Indonesia's finances fragile and easily arises. Such conditions, both directly and indirectly, have made state finance more burdened from year to year. Based on these data and facts, the government has taken an important step in 2014 by establishing a policy to memorize the formation of new autonomous regions. Although the division is a regional constitutional right, but the government stated that the current state finances are still focused on financing development infrastructure and resolving the problem of a large budget deficit before re-issuing permits for the formation of new autonomous regions. The formation of new autonomous regions is carried out if the state finances are sufficient because a large budget is needed to build facilities and infrastructure that will support the new autonomous regions

Several studies have tried to examine what happened in some new autonomous regions. Ministry of National Development Planning has conducted a study on accelerating the development of new autonomous regions. The study specifically examines issues related to new autonomous regions development and sectors that are a mainstay in economic development. The study took place in Serdang Bedagai Regency (North Sumatra), Sekadau Regency (West Kalimantan), West Sumbawa Regency (West Nusa Tenggara), Tomohon City (North Sulawesi) and Tasikmalaya City (West Java). The results of the study showed that regional own-source revenue increased, but the dependency on the General Allocation Fund remained high. There has also been an increase in development spending, although the proportion of routine expenditure is still small. It is not surprising if the respondents said the quality of community services had not improved. This was apparently due to the new autonomous regions regional government in the early years prioritizing the improvement of the institutional, institutional infrastructure, personnel and regional finances (National Development Planning Agency, 2008).

The Ministry of Interior's Regional Autonomy Research and Development Center (2013) also studied the effectiveness of regional expansion in the era of regional autonomy in nine new autonomous regions. This study concludes that in general there is no new autonomous regions that can be grouped into the category of able, even though the arrangement of various aspects of government to support governance is in accordance with existing guidelines. The study found that the institutions that were formed had

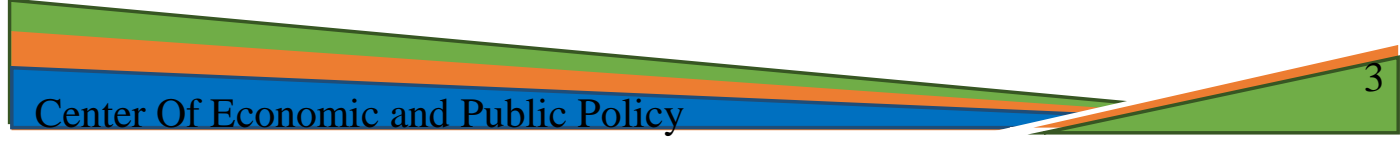


not yet been fully adjusted to the functions that had been designated as regional affairs (Ministry of Internal Affairs, 2013).

Based on data from the Ministry of Home Affairs, the preparation process for the formation of the new autonomous regions has so far required funds of up to trillions of rupiah. In addition to the large cost factor, the government is currently completing the draft government regulation on the great design of regional arrangement as the legal basis for implementing regional expansion. The pattern of forming new regions is not like in the past where regions were formed and released just like that. At present, before becoming a new autonomous regions, the division must go through preparatory areas for at least three years. During the three years the area will be seen its development to later see whether it is worthy of being a new autonomous regions or not. Reflecting on the previous division, there are still parent regions that have not yet submitted their grant funds for new regions. This has caused many new autonomous regions to depend on funding from the state budget. These problems also have an impact on state finances.

This study aims to answer the question of the factors that led to the formation of new autonomous regions during the reform era and their impact on state finances comprehensively. From the two studies above as well as several other related studies, in general it discusses the evaluation of new autonomous regions performance or the ability of the economy and its development. While this study focuses more on the driving factors for the formation of new autonomous regions and the impacts that arise on state finances in general.

So, this study is expected to be useful as input for policy makers both in the executive and legislative branches in making the grand design of regional structuring. In addition, this study is also useful as a reference for academics who are interested in the issue of regional structuring. It is hoped that this study can elaborate more deeply and can improve existing studies.

As with the background above, this study is important to do because it seeks to examine more deeply the division of regions and their impact on state finances. In addition to the current national issues regarding the growing state budget deficit, increasing the number of new autonomous regions will certainly add to the budget plot for the new region, the authors determine the title in writing this study is factors for forming a new autonomous region and its impact on state finance.

\section{METHOD}

This study is a policy study that is designed to understand one or more aspects related to the policy process, including decision making, policy formulation, policy implementation, which is conducted using descriptive qualitative study methods. This literature review is carried out by collecting data from the publication of agencies / institutions which are juxtaposed with various literary sources of experts and legislative documents for later analysis to become a conclusion and recommendation. The intended literature and documents can be in the form of books, journals, institutional reports,

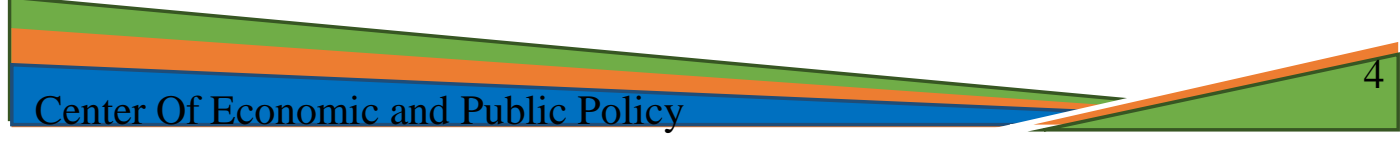


legislation, clauses, media news, academic texts, policy papers and other literature relating to the focus of the study.

The technique for obtaining data in this study is the literature review method and holding discussions with competent officials / experts and documentation. The discussion was carried out by involving the Regional Representative Council of the Republic of Indonesia, the Ministry of Home Affairs, the Ministry of Finance and the National Development Planning Agency in the form of Focus Group Discussions.

The data analysis process in this study starts from the preliminary study to the preparation of the study proposal. The next step, deeper data processing is done by processing the results of the research library and the results of discussions and documentation of various field information. After that, checking the validity of the data used as study informants and comparing the data with various other relevant information. The validity of the data is needed to measure the extent to which the interpretation made by the researcher can be trusted. In qualitative research methods, researchers' interpretation of data is a major strength. This study uses data validity techniques formulated by John Cresswell (2016).

\section{RESULT AND DISCUSSION}

\section{Formation of a Massive New Autonomous Region in the Reformation Era}

The formation of new autonomous regions from 1999 to 2014 showed a significant development, because the number of provinces in Indonesia increased by $23 \%$ and the number of districts /cities increased by $67 \%$. If broken down by district /city, the number of new autonomous regions increases by 205 new districts / cities. So, if calculated on average from 19992014, each year the province's new autonomous regions and regencies / cities increase by 13 new autonomous regions per year.

Graph 1. Development of the New Autonomy Region 1999-2014

$\square$ Province $\square$ District/ City Number of autonomous regions

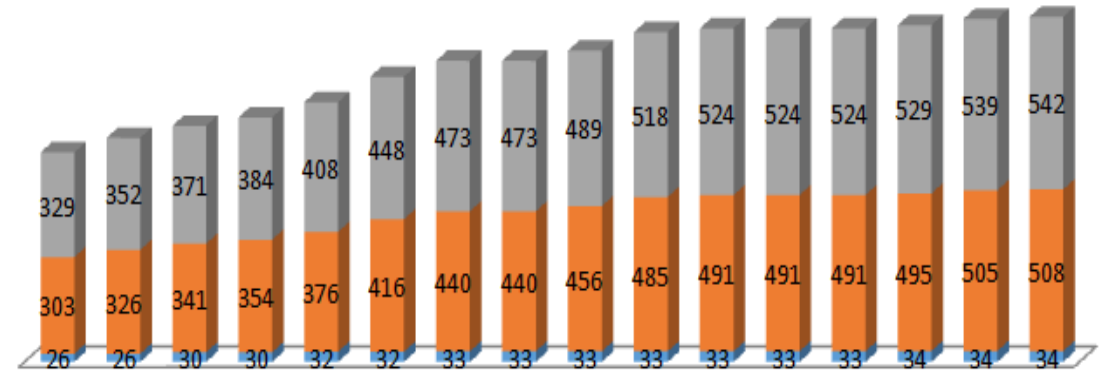

1999200020012002200320042005200620072008200920102011201220132014

Source: Ministry of Home Affairs

The formation of a new autonomous region was a euphoria after reform. This is caused by the existence of very strict rules that apply in the very centralized New Order era. This changed when the new order collapsed and a decentralized system began to be implemented, which in turn made the trend for the formation of new autonomous regions even more intense. The

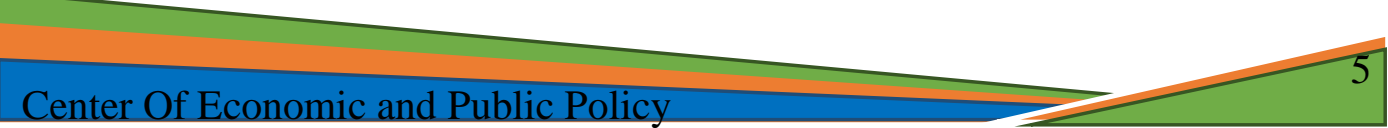


Ministry of Home Affairs conducted a study in 2010 to estimate the addition of new autonomous regions until 2025, the results of which are as follows:

Table 1. Estimated Number of Autonomous Regions 2010-2025 in Indonesia

\begin{tabular}{cccc}
\hline Daerah Otonom & $\mathbf{2 0 1 0}$ & Penambahan & $\mathbf{2 0 2 5}$ \\
\hline Provinsi & 33 & 11 & 44 \\
Kabupaten/Kota & 491 & 54 & 545 \\
Jumlah & $\mathbf{5 2 4}$ & $\mathbf{6 5}$ & $\mathbf{5 8 9}$ \\
\hline
\end{tabular}

Source: Ministry of Home Affairs

Until now, given the large demands for the formation of new autonomous regions from various provinces throughout Indonesia, it is not impossible that such estimates will occur and create new autonomous regions. This condition certainly has its own impact on government finances, both the central and regional governments.

\section{Drivers Of The Formation Of A New Autonomous Region}

The formation of new autonomous regions through the process of expanding autonomous regions has been known since the founding of this republic. During the New Order administration, regional expansion occurred in very limited numbers. Most of the formation of autonomous regions at that time was the formation of municipalities as a consequence of the process of urbanizing a part of a Regency. The process also begins with the formation of an administrative city as an administrative territory, which can then be formed into a municipality as an autonomous region. The process of regional expansion is more top-down or centralized, dominated by technocratic administrative processes. Since the implementation of decentralization through the enactment of Law Number 22 Year 1999 concerning Regional Government which was later revised to Law Number 32 Year 2004, the regional expansion policy has experienced significant changes.

Although the conditions for the formation of regions in Government Regulation No. 78/2007 have been made even more stringent, they have not been able to stem the demands of the regions to expand and form new Regions. According to Eko Prasojo, there are a number of driving factors for making demands for regional expansion so far (Prasojo, 2011), namely:

a. First, the demand for expansion is a legal way to encourage the government to channel state finances to the regions. As long as the financial incentives are in the form of general allocation funds, allocation funds or other balancing funds from the central government continue to flow into the new autonomous region, so long as the demands for expansion will occur. In other words, expansion is a tool for new regions to pressure the central government to give money to it.

b. Secondly, besides having a dimension of state finance, expansion also has a political dimension. Expansion is a political way to provide greater space for cadres of political parties in the region to take part in

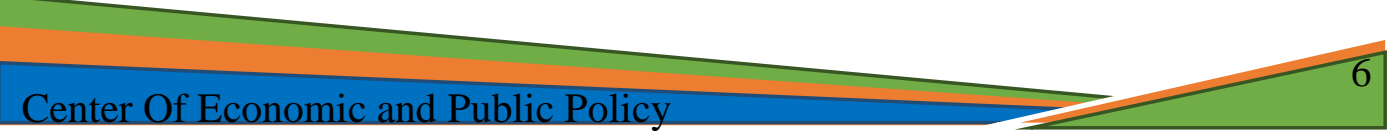


representative institutions and other regional government institutions. The formation of a new autonomous region was clearly followed by the formation of a number of structures and positions in the region such as regional heads, deputy regional heads, members of the Regional People's Representative Council and other positions. Not surprisingly, members of the House of Representatives have a high interest in continuing to take the initiative to draft a bill for the formation of a new autonomous region.

c. Third, expansion can also have the dimension of the promise of politicians to the people in their constituencies. Especially before the election, the promise of the formation of a new autonomous region will be an effective campaign tool to boost votes in the election. The counter opinion of the division can be seen as not pro-regional and not pro-people.

d. Fourth, of course it is very legitimate to state that from the area and range of services, expansion is a way to bring services closer together while increasing the prosperity of the people.

In line with this argument, as a consequence of the enactment of the regional autonomy system, there are several factors that can trigger regional expansion, including:

a. Administrative Dispersion (overcoming the range of government control), this reason is increasingly strong considering that the regions of expansion are quite large areas while the center of government and community services are difficult to reach. The position of the government capital is a determining factor. It is also evident that the newly created regions are underdeveloped and poor areas with very little support for public services and supporting infrastructure.

b. Inequity Resistance (injustice factor), injustice is also a trigger factor for demands for regional expansion. The party who proposes the burning of the region feels that the amount of regional income is not proportional to the welfare of the people in the region and this creates an imbalance in welfare between one region and another.

c. Bureaucratic and Political Rent Seeking (political reasons and to seek important positions). Political reasons where with the existence of new territories will bring up new areas of political power so that people's political aspirations are much closer. At the regional level, of course, this opportunity will arise through executive and legislative powers. At the national level, the emergence of new territories will be utilized as an opportunity for greater support for certain political forces.

d. Fiscal Spoil (fiscal incentives for self-expansion, the existence of guarantees of transfer funds, especially the General Allocation Fund from the central government to regional governments, generate confidence that the newly formed regions will be funded.

e. Preference of Homogeneity, reasons for differences in identity (ethnic or cultural) also often appear as one of the reasons for expansion. The desire to form new territories is in line with the increasingly strong

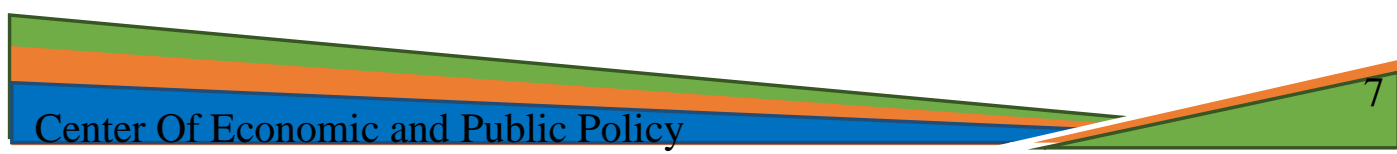


tendency of ethnic groupings in the old territories. The demand for expansion arises because usually the people domiciled in the expansion area feel as a separate cultural community different from the parent cultural community (FGD results).

Of the five factors above, when juxtaposed with the theory of decentralization as revealed by The Liang Gie, then:

a. The area wide factor can be seen from the perspective of organizational technical governance in which to achieve an efficient government, the range of control between the central government and its people must be shortened.

b. Factors of injustice and political reasons for seeking important positions can be seen from a political standpoint, where the implementation of decentralization is seen as an act of democratization, to attract people to participate in government and train themselves in using democratic rights.

c. Factors of ethnic and cultural differences can be seen from the perspective of culture, where decentralization needs to be held so that there is attention to the specificity of a region.

The various political economy interests in the formation of new autonomous regions often make it difficult for the government to withhold the formulation of the law on the expansion of initiatives from the House of Representatives. In the end, regional technical, administrative and physical measures as stipulated in government regulation No. 78/2007 were defeated by political interests and decisions. In other words, that the purpose of expansion for prosperity and welfare of the people is replaced by the interests of the political elite, both at the central and regional levels.

Actually, the phenomenon of expansion needs to be seen from the side of proposers (why they want to form a new autonomous region) and the formulation of policies in the central government. In terms of proposing the formation of a new autonomous region from the region, the enthusiasm \& energy to propose and fight for regional expansion is driven by several reasons, namely:

a. Arguments for bringing government closer to the people, improving the quality of public services, economic development and democracy in the regions. Through the formation of new autonomous regions, isolated regions can then develop into centers of government activities, services and economic activities.

b. Second, often the formation of new autonomous regions is driven by the subjective interests of actors in the regions can also be a motivation for proposing the formation of new autonomous regions, such as politicians and bureaucrats who get wider promotion space, people who feel more politically and culturally valued, and business people who expect activities. Therefore, the proposed expansion of new autonomous regions will continue if there is no clear and firm policy format. 
Then, from the perspective of policy makers in the central government (why it was divided), there is a long policy process, both technocratic and political processes, which must be surpassed by proposals for the formation of autonomous regions. In addition to meeting the technocratic requirements set out in Government Laws and Regulations, the expansion proposal must be politically supported by the Trusteeship Council. Therefore, in order to understand the expansion policy process, it is necessary to track why and how the national government passed the proposed expansion of autonomous regions. Looking at the results of the formation of new autonomous regions which were almost one hundred percent compared to the number of autonomous regions before 1999, it can be said that the government is relatively easy to pass the proposed expansion of the region. There are several possibilities why this might happen:

a. A technocratic process that is easily fulfilled, tricked or ignored. This can happen because of several things, such as the eligibility criteria of expansion that are easily penetrated.

b. Political processes that tend to be bottom-up provide great opportunities, including to propose, mobilize, or politicize proposals for the formation of new autonomous regions. It was also made worse by politicians who tended to support the division of political arguments, as well as the formulation process taken over by the House of Representatives as a proposal for the House of Representatives initiative. (FGD Results)

\section{Formation of a New Autonomous Region and Its Impact on Transfer Funds}

As explained in the theoretical framework related to fiscal decentralization, that fiscal decentralization is one of the consequences of applying the principles of decentralization and regional autonomy. This is reflected in the majority of the state budget which annually flows to all regions of the country. As stated by (Mardiasmo, 2009), related to the initial objective of fiscal decentralization is to reduce the fiscal gap between the central government and regional and regional governments. It is also expected to increase the quality of public services in the regions and reduce the gap in public services between regions.

One of the instruments of fiscal decentralization policy is the policy of transfer to the regions. In 2012, the transfer policy to the regions was implemented through a funding system that paid more attention to aspects of the fiscal gap between the center and the regions, the division of government affairs between the center, provinces, and districts / cities, the quality and disparity of public services between regions, development of regional economic potential, efficiency utilization of national resources, synchronization of national and regional development planning, accelerated development in the most remote, outermost, frontier, and former conflict areas.

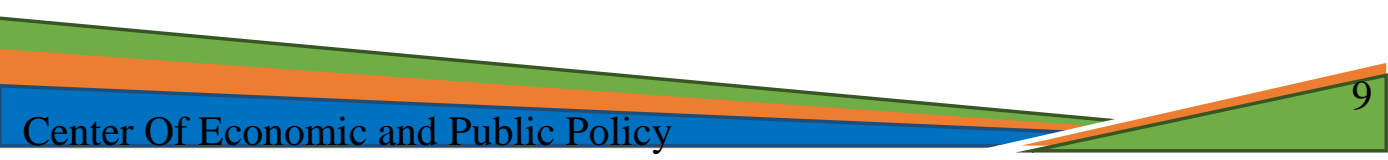


The funding system is in the form of a budget allocation for transfers to the regions in the State Budget, which consists of: (1) Balancing Funds, (2) Special Autonomy Funds and Adjustments. The Special Autonomy and Adjustment Fund is allocated to the regions based on the revenue of the State Expenditure Budget to fund regional needs in the context of implementing decentralization. The Special Autonomy and Adjustment Fund is sourced from the state revenue that is collected, in the form of tax revenue and natural resource revenue. The Special Autonomy Fund and Tax Adjustment consist of Clause 21 income tax (Income tax Clause 21) and Clause 25 income tax and Clause 29 Domestic Personal Taxpayer (Income tax Clause 25/29), Land and Building Tax, and Tobacco Product Excise (FGD Results) ).

The general allocation fund is allocated to minimize interregional fiscal imbalances in funding governmental affairs which are under regional authority. General allocation funds are allocated to provinces and districts / cities based on the total amount of the general allocation funds (nationally) which are finally determined in the State Budget, which is at least 26 percent of net domestic revenue. The proportion of the general allocation funds between provinces and districts / cities is determined based on the balance of authority between the provincial and district / city governments. The proportion of the general allocation fund for provinces is set at 10 percent and for districts / cities at 90 percent.

Meanwhile, the special allocation fund is allocated to assist regions in funding programs / activities that are the authority of the regions and become national priorities. The goal is that the regions can provide adequate infrastructure and public service infrastructure in accordance with the minimum service standards in each field (FGD Results).

\section{Graph 2. Development of Transfer Funds 2004-2018}

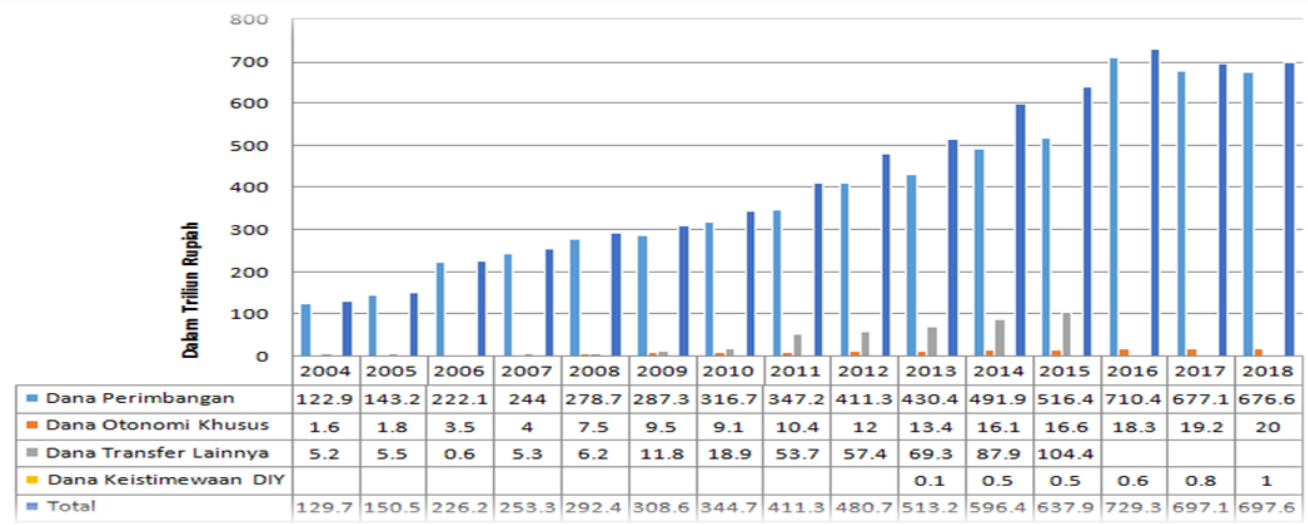

Source: Ministry of finance

In line with the increasing number of new autonomous regions formed, funding needs for the provision of public service infrastructure and infrastructure in the regions also continue to increase. This causes the transfer budget to the regions from year to year also increased. In 2004, the allocation of the transfer budget to the regions consisting of the Balancing Fund, Special

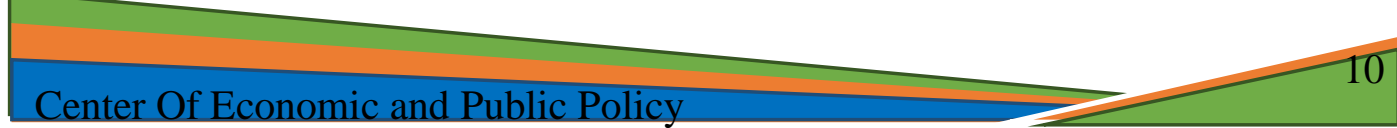


Autonomy and Adjustment Funds amounted to Rp129.7 trillion, then now in 2018 it became 697.6 trillion. More detailed changes can be seen in the table below.

Table 2. Percentage of Increase in Transfer Funds 2004-2018

\begin{tabular}{ccc}
\hline Year & $\begin{array}{c}\text { Allocation of Transfer Funds } \\
\text { (in Trillions of Rupiah) }\end{array}$ & $\begin{array}{c}\% \\
\text { Increase }\end{array}$ \\
\hline 2004 & 129.7 & - \\
2005 & 150.5 & 13.82 \\
2006 & 226.2 & 33.47 \\
2007 & 253.3 & 10.70 \\
2008 & 292.4 & 13.37 \\
2009 & 308.6 & 5.25 \\
2010 & 344.7 & 10.47 \\
2011 & 411.3 & 16.19 \\
2012 & 480.7 & 14.44 \\
2013 & 513.2 & 6.33 \\
2014 & 596.4 & 13.95 \\
2015 & 637.9 & 6.51 \\
2016 & 729.3 & 12.53 \\
2017 & 697.1 & $(4.62)$ \\
2018 & 697.6 & 0.17 \\
\hline
\end{tabular}

Source: Ministry of finance

Furthermore, based on the analysis of the Indonesian State Budget over the past 10 years, it can be seen that due to the state budget policy in that time span, the state finances experience a deficit every year because the state budget is always greater than state revenues. In covering the annual budget deficit, the government's decision to owe money is indeed very logical to cover the entire deficit.

Although the budget allocation for transfer to regions in the last five years has always increased in the aggregate, but since 2017 the growth trend has tended to decline. Transfer funds increased by only 0.17 percent from rp697.1 trillion (2017 state budget) to rp697.6 (state budget 2018). In fact the allocation of general transfer funds consisting of general allocation funds and revenue sharing funds decreased 2.6 percent compared to the allocation in the previous year. This condition is caused by the realization in the field that is not massive enough. The government claims that the funds have succeeded in reducing poverty and gini ratios in the regions, but the impact on improving people's living standards is still not significant enough 
Graph 3. Development of the 2008-2017 National Budget

$\square$ Deficit

State Expenditure

Country Income

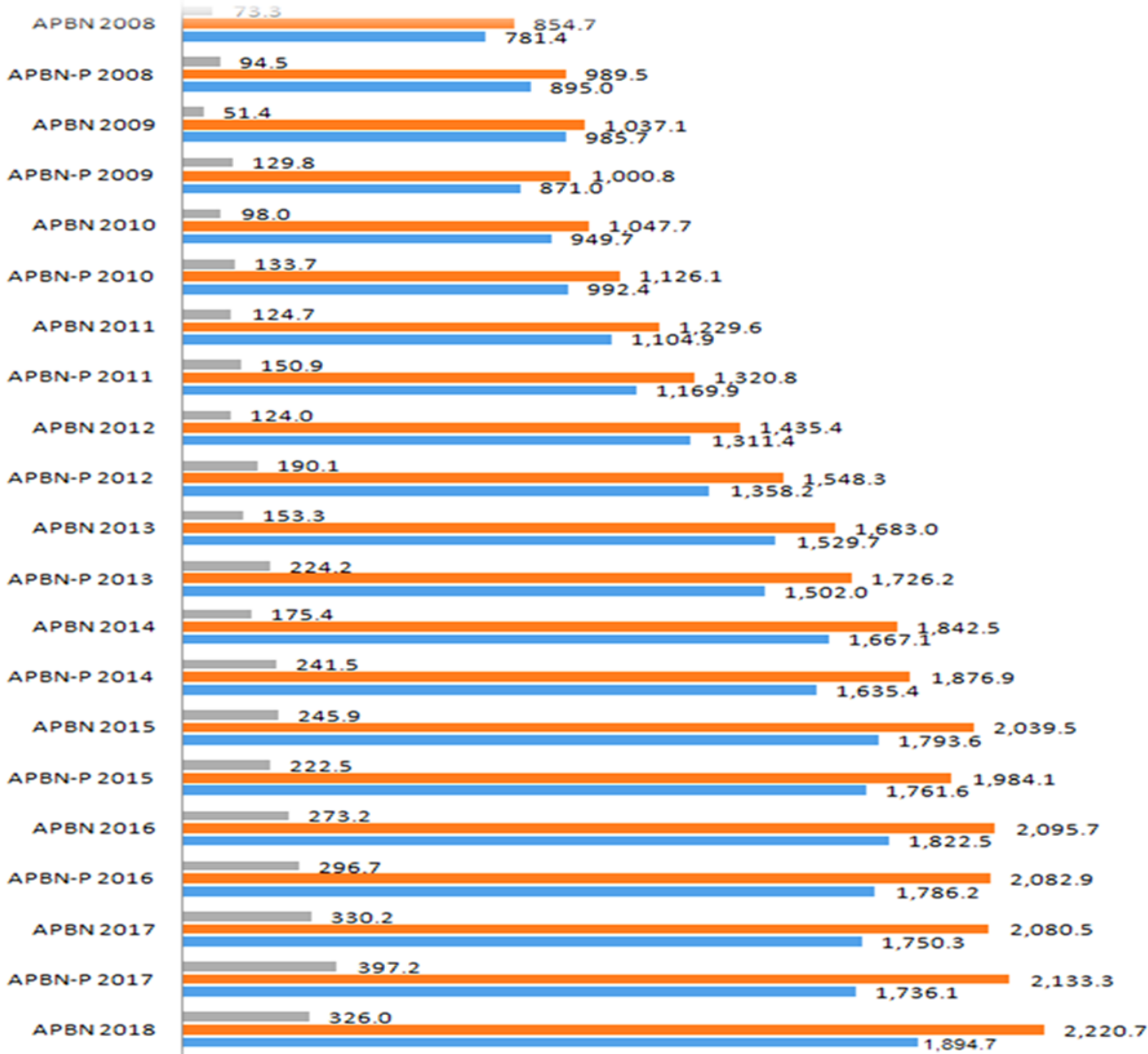

Source: Ministry of finance

\section{Forming a New Autonomous Region Requires a Large Budget}

In discussing this problem, the theory of decentralization and the concept of regional autonomy are considered suitable to see the paradigm that develops in the formation of new autonomous regions. According to Law No. 23 of 2014, the principle of regional autonomy uses the principle of broad autonomy in the sense that the region is given the authority to administer and regulate all government affairs outside those of the government. On the other hand, to look at it from a financial perspective, the formation of new autonomous regions is an effect of decentralization which aims to reduce the fiscal gap between the central government and regional governments. Therefore, based on the count of the Ministry of Home Affairs, the preparatory process for the formation of new autonomous regions requires funds of up to trillions of rupiah. In fact, the state budget deficit is increasing from year to year (as previously explained). This is similar to what Anwar (2014) found that with an imbalance between expenditure and revenue (budget deficit), then it automatically becomes a burden on state finances.

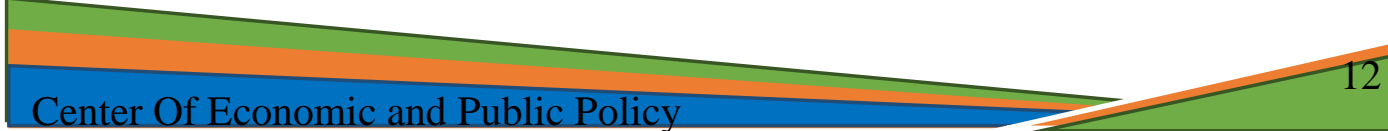


If the formation of a new autonomous region is not moratorium, based on data from the proposed regional preparation for a new autonomous region, the total estimated funding requirement for the formation of a new autonomous region is $\mathrm{Rp} 22,112,500,000,000$. At present there are at least 101 regions that have been proposed to be formed until 2025. All of these regions comprise 11 provinces, 78 districts and 12 cities throughout Indonesia. It's just that the expansion effort is currently suspended (moratorium) by the government (FGD Results). The breakdown of the cost of establishing a preparation area for the province is Rp. 30,250,000,000, Rp. 156,000,000,000 districts and $\mathrm{Rp}$. 24,000,000,000 cities. As for the cost of conducting the preparation area of $\mathrm{Rp} 21,902,349,000,000$. For the province of Rp. 4,546,938,000,000, Rp15,041,356,000,000 districts, and Rp24,000,000,000 cities. Therefore, the formation of new regions should not be carried out without in-depth study. (FGD results).

Apart from that, it is certain that each new autonomous region will still depend on funding from the state budget, while the original regional revenue, the new autonomous region will only average $5-10 \%$. Not only the new autonomous regions, even the majority of old regions still depend on the state budget. Only DKI Jakarta has genuine regional income (FGD Results). Basically, regional expansion is a constitutional right owned by each region. That is, as long as it meets the requirements, in fact each region may only propose the formation of a new autonomous region. However, in a state where financial difficulties are occurring, the momentum is very improper if the division is renewed at this time. In addition, the government is currently still evaluating the implementation of the new autonomous region that was formed until 2014 so that a moratorium on expansion is currently being established. The government said that the temporary division could not be continued. The reason is the unstable economic conditions. Therefore for the 2018 budget discussion has not been included on the new autonomous regions. This is to anticipate that the formation of new autonomous regions will no longer be a burden on state finances.

The moratorium on regional expansion is carried out so that the government can focus on improving the economy without having to worry too much with additional spending on new regions. The postponement of the formation of new autonomous regions is used as a preparation period for regions that want to form new autonomous regions. More careful preparation must be done so as not to negatively impact the country's finances. The ministry of home affairs stated that if after the discussion of the new autonomous region it could immediately produce the newly created region, it would now have to wait three years. Even then, after an assessment conducted by the central government to assess the feasibility of forming new regions.

The moratorium was carried out to prevent new regions failing due to lack of preparation. During the preparation period, several requirements were prepared, starting from the legal umbrella, regional boundaries, maps, to asset and financial management. Meanwhile the director general of regional

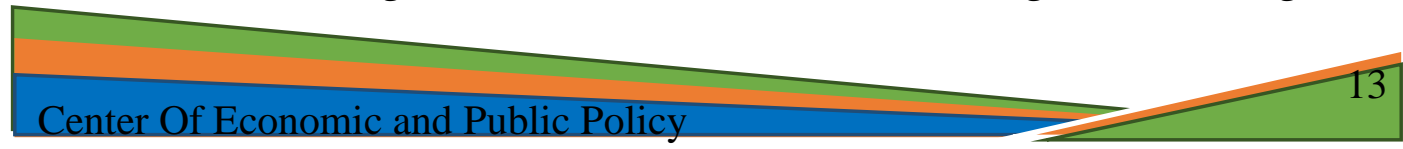


autonomy at the ministry of home affairs also stated that the moratorium on the formation of a new autonomous region will continue to take effect this year due to budgetary problems. During the moratorium period, the ministry of home affairs will further optimize existing funds for the needs of infrastructure development and border areas (FGD results).

\section{Formation of a New Autonomous Region in a Cost and Benefit Perspective}

The rearrangement of the new autonomous region is still very identical to regional expansion, none of which have led to the elimination and merger of regions as regulated in regulation Number 129 of 2000 concerning requirements for the establishment and criteria for expansion, elimination and merger of regions which were then replaced with regulation Number 78 Year 2007 concerning procedures for formation, elimination and merger of regions. The establishment of new autonomous regions since 1999 shows a significant development, because the number of provinces in Indonesia increased by $21 \%$, the number of districts increased by $41 \%$, and the number of cities increased by $37 \%$.

In the regulation prerequisites for the formation of a provincial region must cover a minimum of five districts / cities, while for districts consisting of five districts and cities with only four districts. On the other hand, the formation of subdistricts, wards and villages is only determined through local regulations. So it is unable to be monitored by the government, given the absence of a continuous reporting or recording system of regional regulations at the central level. Based on the recording of the ministry of home affairs in 2008 , it is known that on average each month 18 sub-districts, 30 villages and 60 villages are formed.

Considering the purpose of regional autonomy is to improve the welfare of the community, bring public services closer and strengthen regional competitiveness, the flooding of the level of regional expansion threatens the decline in the quality of regional government administration. The results of the evaluation of the performance of the new autonomous region conducted by the ministry of home affairs stated that only $58.71 \%$ had high performance. The remaining 34.19\% under-performing, and 4.16\% under-performing. Even President Susilo Bambang Yudhoyono himself once launched $80 \%$ of the new autonomous regions failed to improve welfare. Another fact from the evaluation results of the ministry of development of disadvantaged regions shows that 34 regions have become disadvantaged or poor after being divided.

In the period 1999-2009, there were 205 new autonomous regions consisting of 7 Provinces, 164 Regencies and 34 Cities. As a result in 2003, the government had to provide a general allocation fund of Rp1.33 trillion for 22 new autonomous regions resulting from the division which was carried out in 2002. That number doubled in 2004, where the government had to transfer Rp2.6 trillion of the general allocation fund allocation for 40 new autonomous regions. In 2010, the government disbursed Rp.47.9 trillion in funds as general allocation funds for new autonomous regions. Since the motivation for the birth of a new region is more political and based on the spirit of taking a

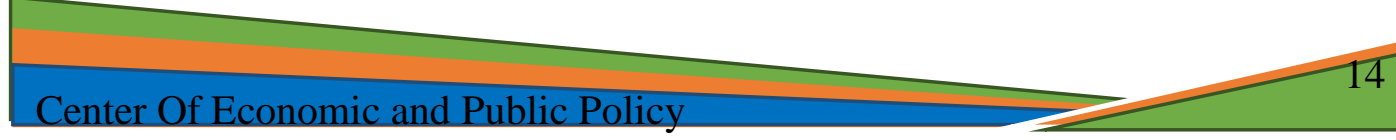


bigger budget, the only way to control the pace of regional expansion is to revise the rules regarding general allocation funds. Through the momentum of the revision of the financial balance law, a binding arrangement must be affirmed that the new autonomous region cannot automatically obtain general allocation funds (FGD results).

The number of regulations relating to regional expansion in a relatively short period of time is an "extraordinary" achievement, while raising several big questions in our minds. First, is the formation of new autonomous regions important as a solution to improve people's welfare? Second, are there really so many interests from regional stakeholders that regional expansion is considered able to accommodate these different interests? Third, did regional expansion occur because new autonomous regions received less attention from parent regions?

Let us try to examine again, what benefits will be obtained from an area expansion. The main advantage is surely to shorten the span of control between local government and the community, especially in areas that are not yet covered by government facilities or infrastructure. In addition, regional expansion also improves the distribution of development. Based on past experience, the regions that were the initial focus of development were only areas that were close to the government capital.

Another advantage is of course for the political elite in the region and the regional officials themselves. With expansion, an area can get a general allocation fund, the amount of which can reach twice the previous level, because a new region will get a general allocation fund that is relatively the same as its parent region. Factors like this are often the reasons for proposing the formation of regions never stop. In addition, expansion also opens opportunities / opportunities to benefit from regional expansion, both funds from the Government and from the region's own revenues.

Conversely, when viewed from the side of the state's financial burden to finance this, the formation of a new autonomous region makes the general allocation fund that must be prepared by the government to be bigger. This has not been added to the additional budget of the state budget which must be prepared to finance the salaries and allowances of newly appointed regional officials, while the amount of costs incurred does not necessarily guarantee an increase in the welfare of the people which is the main objective of the formation of the new autonomous region itself .

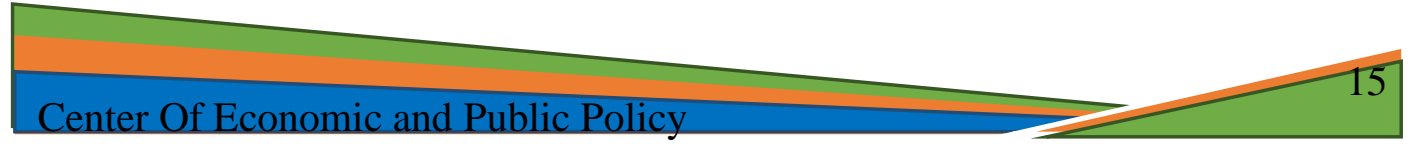


Table 3. Composition of the 2014 Autonomous Regional Budget (Before The Moratorium On New Autonomous Regions)

\begin{tabular}{ccccc}
\hline & 319 Old Regions & \% & 213 New Regions & \% \\
\hline $\begin{array}{c}\text { Total } \\
\text { Income }\end{array}$ & 359.177 .321 .880 .740 & 100 & 119.920 .844 .221 .726 & 100 \\
$\begin{array}{c}\text { Locally- } \\
\text { generated } \\
\text { revenue } \\
\text { Balance } \\
\text { Funds }\end{array}$ & 81.513 .189 .343 .563 & 23 & 8.880 .068 .568 .928 & 7 \\
$\begin{array}{c}\text { Other } \\
\text { Income }\end{array}$ & 47.058 .776 .813 .988 & 12 & 14.284 .852 .940 .362 & 12 \\
\hline
\end{tabular}

Source :Ministry of Internal Affairs

From the table above it can be seen that the balancing fund is the largest revenue contributor of the total 2014 regional expenditure budget. The total funds for 213 autonomous regions have only reached $81 \%$ of total revenue, while the old regions are $65 \%$. The new autonomous region is still unable to explore its original regional revenue, as seen from the total regional original income which is only $7 \%$ of the total amount. From the table above shows the amount of original regional income is smaller than the amount of regional income so that regions are even more dependent on the central government through funds transfers to the regions in the state budget every year. From other data we can also see, for example in the 2012 - 2014 time frame 12 new regions have been formed. But, if we look generally at regional finance in the same timeframe, it can be concluded that many regions still depend on equilibrium funds from the center, and are inversely proportional to the region's original revenue.

Graph 4. Regional Expenditures / Defist 2013-2015

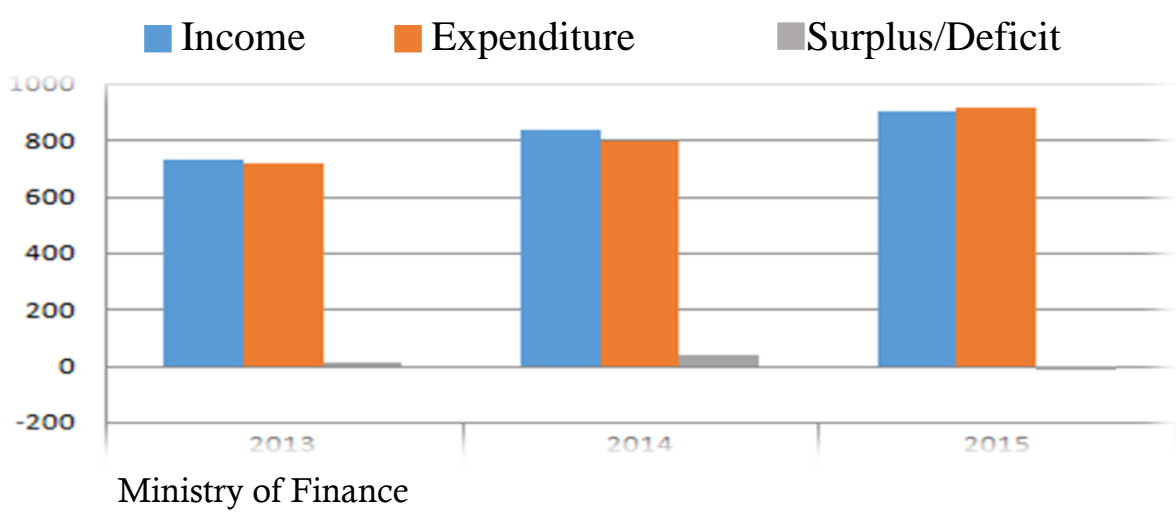


Graph 5. Realization of Regional Revenues 2013-2015

Amount Others locally-generated revenue Balance fund

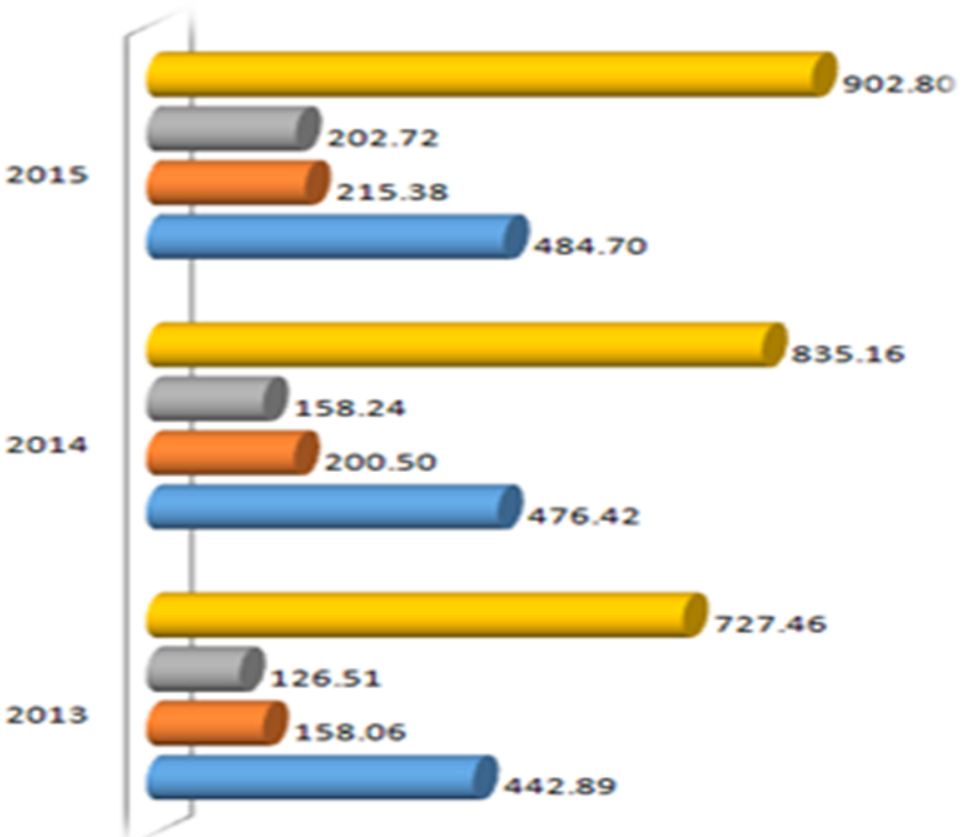

Ministry of Internal Affairs

Graph 6. Realization of Regional Expenditures 2013-2015

Other Expenditure

Goods \& Services Expenditure

Capital Expenditure

Employee Expenditure

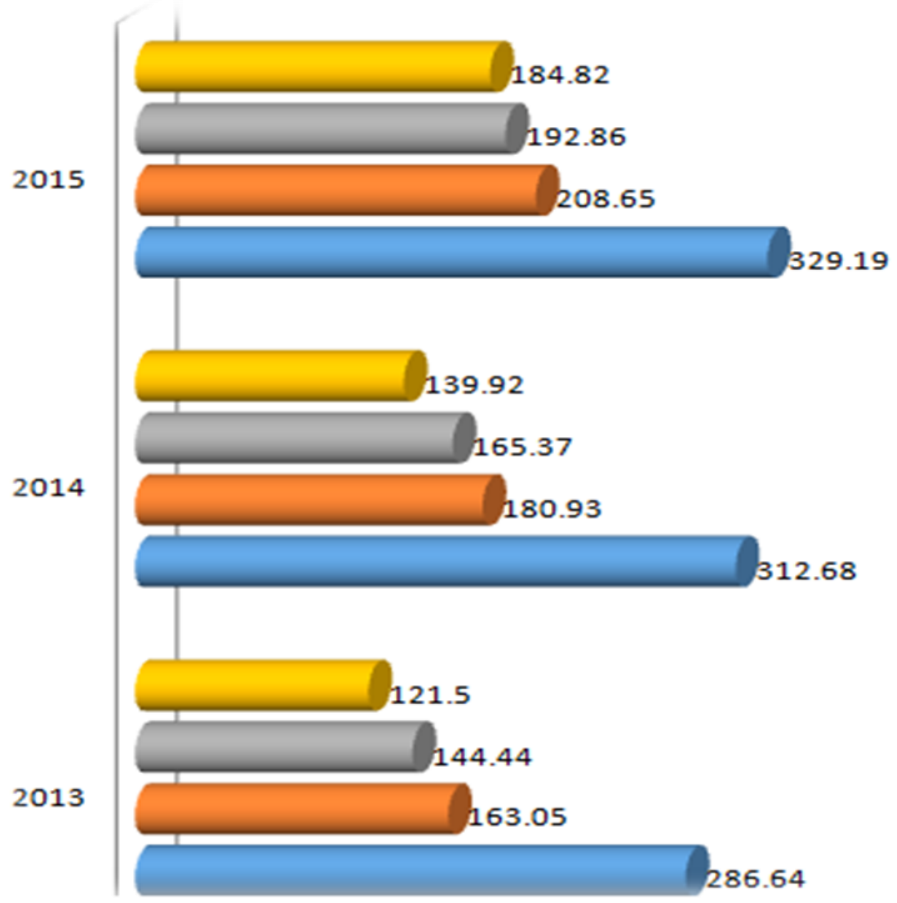

Ministry of Internal Affairs 
To finance the running of government and development, local governments are still largely dependent on the central government such as general allocation funds and special allocation funds. Most of the general allocation funds have been absorbed by employee expenditure of around $50 \%$ (in the indirect expenditure group). In fact, when seen from the criteria for a healthy regional budget structure, the direct expenditure is higher than the indirect expenditure. Therefore, from the stipulation of Law Number 6 Year 2014, the structure of regional income and expenditure budget is not healthy / not ideal, because direct expenditure will be low compared to indirect expenditure.

From these data it can be stated that the ideal balance of central and regional finances is if each government can be independent in the financial sector to finance the exercise of their respective authorities. Therefore, the central assistance which has been the main source of revenue from the regional revenue and expenditure budget should start to reduce its contribution and the main source of revenue is from the region's own original revenue. However, most regions have not been able to increase their own sources of income. So it can be said that the regional / regional government is still not independent, because in general it still depends on the balance fund.

In this era of decentralization, the performance of the formation of new autonomous regions has not been in accordance with its objectives, namely to improve people's welfare. This is due to the financial performance of new regions as a means to achieve these goals, in fact decreasing along with the increase in the formation of new autonomous regions. On average in each of the new autonomous regions, the receipt of balance funds from the center is more directed at the development of government infrastructure such as government offices, official housing, and other expenses related to employee spending.

Expenditures related to spending on civil servants clearly have little effect on the surrounding community. Provision of public goods to the public will certainly be reduced because in the early years of the formation of the new autonomous region, development is more focused on the construction of government facilities. Therefore, the flow of general allocation funds to the newly created regions becomes an opportunity loss for the provision of infrastructure and public services. Thus, the financial investigating body has a strategic role to assist the house of representatives, the regional representatives council and the regional people's representative council in overseeing the budget to be more effective and efficient so that a clean government is created by carrying out an examination of financial management and responsibility in accordance with the mandate of Law Number 15 of 2004 concerning the Audit of Management and Responsibility of State Finances.

\section{CONCLUSION}

The formation of a new autonomous region in reality cannot be an alternative in accelerating development. But on the other hand, the formation of new autonomous regions is also not something that should be avoided

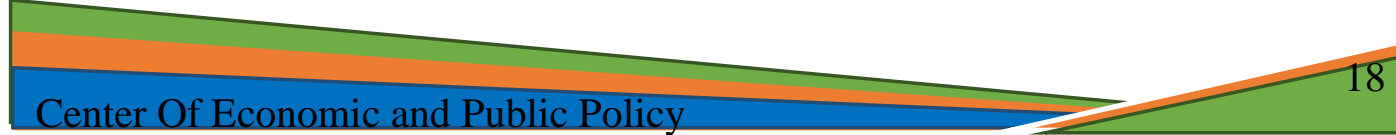


forever. It is important for the central government to pay special attention to new autonomous regions. In this case the attention to the areas that had already been dislocated and did not show progress.

In general, the financial performance of new autonomous regions is lower than in parent regions. So far, the financial performance of new autonomous regions tends to be constant, while the financial performance of parent regions tends to increase. That causes the new autonomous regions to have higher fiscal dependence compared to parent regions with widening inequalities. The division also encourages greater dependence in the area of expansion compared to the parent region and other districts in general.

The formation of new autonomous regions often uses normative reasons to be realized, such as shortening the range of control between local government and the community and creating equitable development. In fact, it shows factually that most of the formation of new autonomous regions is only for 'sharing' power at the local level. As a result, the administration of government in the new autonomous region has become ineffective and the country is increasingly burdened by a growing budget deficit.

Apart from the pros and cons, the moratorium on regional expansion that has been implemented by the government from 2014 still needs to be continued. This is because the preparatory process for the formation of new autonomous regions requires funds of up to trillions of rupiah. Though the country's finances are still experiencing a deficit that is increasing every year. The situation will be further aggravated if the formation of new autonomous regions continues to emerge.

Increasing local own revenue is one of the right efforts to build financial independence. Many studies show that efforts to increase local revenue are to increase capital expenditure and infrastructure to drive greater economic growth, which in turn will increase sources of income. With a significant increase in local revenue, it will certainly reduce the dependence of new autonomous regions on balancing funds so it will not overburden state finances.

\section{REFERENCE}

Anwar, K. (2014). Analisis Dampak Defisit Anggaran terhadap Ekonomi Makro di Indonesia. Jejaring Administrasi Publik, 2.

Bappenas. (2008). Studi Evaluasi (Impact) Penataan Daerah Otonom Baru. Jakarta.

BPP Kemendagri. (2013). Himpunan Hasil Kelitbangan. Jakarta.

Budiardjo, M. (2013). Dasar-Dasar Ilmu Politik. Jakarta: Gramedia.

Creswell, J. D. (2016). Research Design: Pendekatan Metode Kualitatif, Kuantitatif, dan Campuran (4th ed.). Yogyakarta: Pustaka Pelajar.

Harefa, M. (2017). Optimalisasi Kebijakan Penerimaan Daerah. Jakarta: Pustkaa Obor Indonesia.

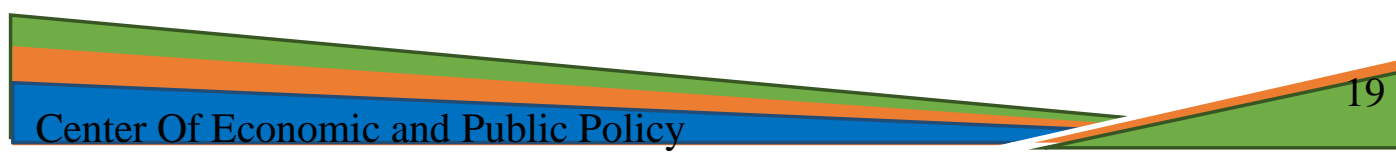


Haryanto, J. T. (2017). Desentralisasi Fiskal Seutuhnya. Retrieved November 25, 2018, from https://www.kemenkeu.go.id/publikasi/artikel-danopini/desentralisasi-fiskal-seutuhnya/\%0A

Huda, N. (2015). Hukum Pemerintahan Desa. Hukum Pemerintahan Desa. Bandung: Nusa Media.

Kaho, J. R. (2002). Prospek Otonomi Daerah di Negara RI. Jakarta: PT Rajawali Grafindo Persada.

Khusaini, M. (2006). Ekonomi Publik: Desentralisasi Fiskal dan Pembangunan Daerah. Malang: BPFE Unibraw.

Litvack, J., Ahmad, J., \& Bird, R. (1999). Fiscal Decentralization in Developing Countries. In Sector Studies Series (p. 48). Washington, DC: The World Bank. https://doi.org/10.1017/CBO9780511559815

Mardiasmo. (2009). Otonomi dan Manajemen Keuangan Daerah. Yogyakarta: Andi Press.

Nadir, S. (2013). Otonomi Daerah dan Desentralisasi Desa: Menuju Pemberdayaan Masyarakat Desa. Jurnal Politik Profetik, 1(1).

Prasojo, E. (2011). Jorjoran Pemekaran Daerah: Instrumen Kepentingan Ekonomi Politik. Spirit Publik, 1(7).

Pratikno. (2011). Usulan Perubahan Kebijakan Penataan Daerah (Pemekaran dan Penggabungan Daerah). Spirit Publik, 1(7).

Sarundajang, S. H. (2002). Arus Balik Kekuasaan Dari Pusat ke Daerah. Jakarta: Pustaka Sinar Harapan.

Siswanto, S. (2012). Hukum Pemerintahan Daerah Di Indonesia. Jakarta: Sinar Grafika.

Soehino. (1999). Ilmu Negara. Yogyakarta: Liberty.

Wijaya, A. (2017). Bahaya Anggaran Negara: Pajak Seret, Proyek Infrastruktur Membebani. Retrieved November 25, 2018, from https://katadata.co.id/telaah/2017/10/14/bahaya-anggaran-negarapajak-seret-proyek-infrastruktur-membebani

Republik Indonesia, Undang-Undang Republik Indonesia Nomor 22 Tahun 1999 tentang Pemerintah Daerah.

Republik Indonesia, Undang-Undang Republik Indonesia Nomor 17 Tahun 2003 tentang Keuangan Negara.

Republik Indonesia, Undang-Undang Republik Indonesia Nomor 32 Tahun 2004 tentang Pemerintah Daerah.

Republik Indonesia, Undang-Undang Republik Indonesia Nomor 23 Tahun 2014 tentang Pemerintah Daerah.

Republik Indonesia, Undang-Undang Republik Indonesia Nomor 09 Tahun 2015 tentang Pemerintah Daerah. 
Republik Indonesia, Peraturan Pemerintah Republik Indonesia Nomor 78 Tahun 2007 Tentang Tata Cara Pembentukan, Penghapusan dan Penggabungan Daerah. 